\title{
Political Transitions and the Sustenance of Identity Politics in Nigeria
}

\author{
Dr. Idris Othman Jibrin \\ Department of Political Science and International Relations, University of Abuja
}

\begin{abstract}
The recourse to individual or group identity in the articulation and pursuit of interests by social forces is a major facet of Nigeria's political process. This is manifested by the increasing deployment of hitherto suppressed identities of ethnicity, religion and regionalism among others, in the contest for political and economic power by various contending forces. It will appear that the resurgence of identity politics is a worldwide phenomenon, and therefore, not restricted to Nigeria. However, the specificity of the Nigerian milieu is conspicuously manifested in various junctures of the national political trajectory, whenever spoils of power are up for grabs. Accordingly, it is hereby contended that identity politics as presently manifested in Nigeria is much a tool for political contest and bargain as it is for personal aggrandizement by the contending political forces. The way out is the total democratization of the national political economy and the attendant institutionalisation of political and economic contest based on popular-democratic grounds as opposed to the prevailing ethno-religious and other primordial grounds.
\end{abstract}

Keywords: identity politics, contending forces, political trajectory, aggrandisement

DOI: $10.7176 / \mathrm{PPAR} / 9-12-07$

Publication date: December $31^{\text {st }} 2019$

\section{Introduction}

The prevalence of identity politics in Nigeria is much a product of the pluralistic configuration of the country as it is of the history of its political evolution. While the British colonialists could be credited with sowing the seed of identity politics in Nigeria through their divide-and-rule tactics, the post-colonial ruling forces have also, through their primitive and unbridled contestation for political and economic power, continued to engender the sustenance, and, even contemporary resurgence of the phenomenon. This is to extent that especially from the period of Babangida military regime's aborted transition programme to date, all hitherto suppressed centrifugal tendencies of ethnicity, religion and regionalism among others, have continued to permeate and dominate Nigeria's political process.

This paper is an attempt to articulate and understand the forces at play in the generation and sustenance of identity politics in Nigeria with the attendant need for adequate response by both government and the society as a whole. This is as informed by the underlying notion that the existence of socio-cultural identities and differences amongst the constituent nationalities of Nigeria is not inconsistent with the institutionalization of a stable and enduring democratic system of governance.

\section{Identities and Identity Politics: Conceptual Clarifications}

Identity is the state of distinctiveness which individuals or groups craves or utilizes to particularise their being and justify the articulation and pursuit of their ends. As a sociopolitical concept, identity can be said to have both an individual and a collective meaning. In terms of individualist conception, it entails a person's consciousness of belonging to a group and the role of such consciousness or sense of belonging in influencing his political behavior or action. Similarly, from the collective point of view it means the sharing of interest by persons belonging in a group. This is to say that, as deposed by Pye (1962:104), "those who share an interest share identity: the interest of each requires the collaboration of all".

The basis for such a sense of belonging and or shared interest among members belonging in a group especially in plural societies like Nigeria could either be ethnicity, nationality, religion, region, kinship relations or even work place affiliations among others. In this regard, it is pertinent to surmise that, as articulated by Jega (2001:15):

Identity is not only about individuality and self-centeredness but also and especially about identification with, and commitment to shared values and beliefs, in a social collectivity into which a person belongs. At any given time, a person may always have multiple identities, each of which may always have some bearing on his or her political contact and social roles in society.

Furthermore, as observed by Salamone (1992), identities are not fixed or permanent social entities or categories as the uses or purposes for which they are subjected to are often changed or transformed by persons who donned them, depending on the times and circumstances at play in a society. In consequence, this leads to 
the additional concept of identity transformation by which is meant to suggest the "changing role of identities and the heightening or increasing magnitude and consequences of identity politics "(Jega, 2000:16).

Arising from the foregoing and by extension, identity politics is nothing other than political action or activity which is engendered, and or centered around the articulation and pursuit of shared interest. In other words:

Identity politics is the political activity of various social movements which represent and seek to advance the interests of particular groups in society, the members of which often share and unite around common experiences of actual or perceived injustice. Such groups argue that they are in some ways socially or politically disenfranchised, marginalized or disadvantaged relative to the wider society of which they form part (Wikipedia, 2005).

However, in the context of political contestation in a developing pluralistic society such as Nigeria, identity politics simply involves "mobilization of identity consciousness in order to create a mass base of support for the ruling classes, and the elite generally in their factional struggles in the accumulation process". (Jega, 2000:16). But first, a consideration of the contentious foundational status of Nigeria.

\section{The Colonial Foundations of Identity Politics in Nigeria}

The foundation for contemporary identity politics in Nigeria had been laid by British colonialism. This was through, inter alia, its "manufacture of differences" amongst the colonized peoples and societies, Indirect Rule policy, urban development and constitutional development.

\subsection{Nigeria as a Colonial Geopolitical Creation}

Nigeria as is known today is a creation of British colonialism. It came about in 1914, when the Colony and Protectorate of Southern Nigeria and the Protectorate of Northern Nigeria were amalgamated and fused into one country by Lord Lugard. The Colony and Protectorate of Southern Nigerian was "a variegated collection of colonial entities, which except for Lagos, had just been conquered by British colonial military occupation" (Usman Abba 2000:45). Similarly, the Protectorate of Northern Nigeria was "a variegated collection of the subjugated, hitherto largely autonomous emirates Sokoto caliphate, the subjugated Sheikhdom of Borno, the Igala and Jukun Kingdoms and numerous independent entities" (Usman Abba, 2000: 46).

Based on this historical fact of its colonial creation, there is a powerful thesis that Nigeria is an artificial edifice that is bound to be afflicted by all sorts of centrifugal tendencies. A representative statement of this school of thought, which is very popular amongst influential sections of the country's political and intellectual circles, could be discerned from the following assertion of a Nigerian scholar "what is today Nigeria was a plethora of various nationalities (ethnic groups) many which had little previous contacts" (Aluko, 2006:33). However, contrary to this popular powerful line of reasoning, Usman and Abba have forcefully underscored the "geographical compactness and interdependence of Nigeria" (2000:52) which favoured its formation by the British Colonies. They buttressed their position by the authoritative exposition of fellow Nigerian historians, Ajayi and Alagoa, who upon tracing and highlighting the "complementarity" of the various geographical zones and "the essential Unity of the river systems", and, how such encouraged prior "greater movement and interaction of people within it than with people outside it"', affirms that:

It is because of this compactness that despite the fortuitous manner in

which the political unity of Nigerian came to be achieved, culturally and economically, Nigeria was not really an arbitrary creation (in Usman and Abba, 2000:49-50).

Hence, if based on the foregoing, Nigeria cannot be dismissed as an arbitrary creation, then the question arises as to how and why is the country's political process dominated by centrifurgal tendencies? To address this poser, the answer should be sought in the very process of the colonial subjugation as well as subsequent formation and evolution of the contemporary Nigerian political economy which produced and unleashed the sociopolitical forces that would serve to generate new social identities with profound enduring impact on the country's political trajectory. Indeed, having invented new "traditions", nurtured and exacerbated an "us" versus "them" syndrome; as well as new identities: viz: "Muslims Versus Christians; Northerners versus Southerners; Hausa-Fulani versus Yoruba versus Igbos and so on "(Jega, 200:76), colonialism could be said to have established the basis for contemporary identity politics in Nigeria through a number of ways.

\subsection{Manufacture of Differences}

The process of the establishment of the colonial state itself engendered what Kuna (2003) has aptly described as the "manufacture of differences" amongst the colonized peoples and societies. This came about through a process of "othering" or the construction of difference which entails "the forcible fragmentation of indigenous peoples and their representation as bearers of separately ethinicised identities in a colonially unified territory" 
(Kuna 2001:4). Two layers of the imposed colonial state were germane to the generation of identity politics in the country. One, is the ranking of states, people and societies or the so-called "homelands" across Nigeria on the basis of the so-called "progress" in social organisation. Those that had established centralised socio political organisation at the time of colonial conquest were ranked as super-ordinates and those without such social organisation, as subordinates. It is on the basis of this "erroneous but powerful imagery of the colonized" that, for instance, "village units, districts and provinces "(Kuna, 2003:6) were carved out in Northern Nigeria. Secondly, the colonial state required the unification and representation of various "homelands" as one homogenous unit in one part of the country and their reconstruction as Northern Nigeria against similar imagined and separate unit as Southern Nigeria. Apart from creating and reinforcing differences and enmity amongst "homelands" within regions, and, between one "unified" region against another, these colonial imaginaries found concrete expressions through "colonial schools, customary laws, administrative and spatial as well as in the strengthening of specific pre-colonial forms of power" (Kuna, 2003:8), which in turn reproduces identities that support them.

\subsection{Indirect Rule Policy}

The second way in which British Colonialism fostered the growth of identity politics in contemporary Nigeria was through the mechanism of Indirect Rule by which Lugard administered colonized Nigeria using existing precolonial "African institutions, authority and personnel" (Nnoli,1978:23). Although this system has been rationalised on the grounds of shortage of personnel, money and communication facilities, yet as contended by Kukah (1993:3), the British rule was "anything but indirect and its cost on the sociopolitical and economic lives of the communities was devastating for it reinforced communal identity where none had existed previously". This was because, not only were religious, regional and ethnic differences used by the British colonialists to conceive and implement policies, including political administration of the various territories and regions, their deliberate usage of population as a criterion for political representation subsequently gave the Northern Nigeria a greater chance of controlling political power nationally to counterbalance the Southern Nigeria's economic and educational dominance. In consequence, the divide-and-rule tactics of British colonialism which attended the indirect rule system not only sowed but also provided a powerful fertile ground for generation of identity consciousness in Nigeria.

\subsection{Skewed Urban Development}

The contact British colonialism established and or facilitated between members of different ethnic groups at urban settings was another major factor in establishing the foundation of identity politics. According to Nnoli (1978), prior to the colonial era, ethnic consciousness and identity as are now known, were none-existent. However, with the advent of colonial capitalism and its attendant social inequality, pervasive insecurity and anomalies, "communal group affiliation and identity in the colonial urban setting" (Nandi, 1978:75) became inevitable. This was accentuated by intense resource competition, social distance and inter-ethnic socioeconomic competition.

Besides, the process of development of the urban centres fostered the emergence of identity consciousness. This was more pronounced in the North where, based on the Land and Native Rights Ordinance of 1940, which vested the control and administration of the native land on the Governor, colonial policy led to emergence of different settlements within the cities. These are, (a) "the Walled city", housing the indigenous population, (b) "Tudun Wada" created by the British to house Northerners who were not indigenous to the town, and (c) "Sabon Gari", the so-called "native foreigners" who "were mainly Southerners "(Nnoli, 1978:116).

In consequence, this development not only resulted in "a greater salience of the ethnocentric component of ethnicity" (Nnoli, 1978:116), but also to others like Bugaje who underscored the religious undercurrent of the phenomenon, colonialism deliberately created 'Sabon Gari' as Christian settlement in Northern Muslim cities to encourage prostitution and drinking of alcohol and gambling, so as to "Corrupt the social morality of the Muslim society within the Walled City “(in Jega, 2000:87).

\subsection{Constitutional Development}

The British colonialism also engendered identity politics through constitutional development. The process began with the Richards Constitution of 1946 which for the first time, divided the country into three regions, namely, North, West and East and consequently "compounded the mutual suspicion among the ethnic groups in Nigeria and marked the beginning of acrimonious ethnic politics in Nigeria". (Albert, 1998:57). This was followed Lyttleton Constitution of 1954, which even though transformed the structure of governance from unitary system to federalism, still "provided for the regionalization of the civil service, judiciary and law-making bodies that each region became freer to run its government as it deemed fit" (Albert, 1998:56). Thus, on the whole, the cumulative effect of the colonial constitutional development process in Nigeria was the encouragement of what Nnoli (1978:54) describes as the "politicization of ethnicity and regionalisation of politics." 


\section{Regionalism and the Margination of Minorities}

As mentioned earlier, the regionalisation of Nigerian politics commenced with the implementation of the Richards Constitution. This, coupled with the subsequent Machpherson and Lyttleton constitutions not only established and operationalised the three regions, but also institutionalized the dominance of the regions by the three major ethnic groups (ie. Hausa-Fulani, Igbo and Yoruba) up to 1967 when the former were broken and twelve states were created by Gowon. However, before then, the British colonialists governed Nigeria as if it were made up of only Hausa-Fulani, Igbos and Yoruba (Tyoden, 1996:248). This is to the extent that problems posed by these inter-ethnic relationships were equated with the problems of the country, and, in that context, so were solutions preferred. The regionalisation of Nigerian politics engendered the marginalization of the ethnic minorities in the country. This was manifested in the domination of the political process by the three major ethnic groups through their dominant regionally-based political parties, namely, the Northern People Congress controlled by the Hausa-Fulani, Action Group by the South-Western Yoruba and the National Council of Nigerian Citizens by the Eastern-based Igbos. Another manifestation was the domination of the regional services by the same majority ethnic groupings as a fallout of the introduction of the Lyttleton Constitution which regionalized the process of governance.

The disadvantaged position of the ethnic minorities was not ameliorated by either the eventual breakup in 1967, of the four-region structure, and subsequent creations of states, or, the politics of revenue allocation in the country which, following policy changes from derivation to principle of population and inter-unit equality (Suberu, 1996:23), tended to favour the majority interests because of the greater number of states and local governments that they have. Suffice it this say at this juncture that the British colonialists entrenched regionalism in the Nigerian body politic not necessarily because they had regional outlook but simply because they needed regionalism to achieve their imperialist goals of exploitation and expropriation of the country's resources. This was by ensuring that the various constituent components of the country remained not only perpetually divided against themselves, but also politically impotent as well. Hence, the continued marginalisation of the minority groups through disproportionate political representation and unequal revenue allocation from the federation account even in the post-colonial era has led to a development of identity consciousness manifested in various incessant contestations and agitations for self-autonomy.

\section{Ethnic and Religious Manipulations}

It may not be out of place to approximate that ethnicity and religion have remained amongst the most recurring decimal in Nigeria's political development. This is also largely on account of the country's composition and the history of its evolution.

Even though it is not certain how many nationalities or ethnic groups are found in Nigeria, they are estimated to be between a minimum of 250 and a maximum of 400 (Idris, 1998:1). Each of these ethnic groups has its language and custom, and is adherent of any or more of the main religions, namely, Islam, Christianity and African Traditional religion. In addition, there are amongst these, as noted in the proceeding section, majority ethnic groupings such as the Hausa-Fulani, Yoruba and Igbos who are numerically dominant in the Northern, South-Western and South-Eastern parts of the country. Similarly, there are numerous minority ethnic groupings which are found in all parts of the country.

Given this complex socio-cultural configuration of Nigeria coupled with its neo-colonialist capitalist orientations which places emphasis on the ethos of individualism and self-aggrandizement, it is certain that ethnic and religious identities would be created and utilized in the process. At the root of this is the selfaggrandizing tendencies only of the national political process in which the contending forces are at liberty, and always, sees and utilizes extant primordial factors as means to an end.

In respect to ethnicity, broadly seen here as the "mobilization and politicisation of ethnic identity" (Egwu, 2001:12), Toyo (1986) has identified about five factors which constitutes the basis of the phenomenon in Nigeria. These include the fact of the ethnic group serving as a vital unit of collective survival in pre-industrial society like Nigeria, the memory of oppression of one people by another which occurred in pre-colonial times, uneven development of the country fostered by colonialism and continued by neo-colonialism, the divide-and-rule tactics of British imperialism and the political underdevelopment of the ruling class leading to domination of national politics by the bourgeoisie.

The significance of ethnicity in the national politics has been manifested not only in the contest for political power and the search for political leaders which have mainly been confined to the three major ethnic groups (Salihu, 2005), but also in the distribution of resources and amenities creating "a situation in which certain ethnic groups are perceived to have enjoyed certain advantages" (Egwu, 1998:18). In consequence, there has been the emergence of new ethnic "territorial movements such as the Ijaws People Coongress, Middle Belt Forum People Congress, Indigenous People of Biafra and the Odua among others.

Even at that, however, it should be noted that the ethnicisation of the national politics is informed by the character and motifforce of the Nigerian political economy. This is in the sense that the ruling forces uses the 
ethnic card in political contest amongst and between their fractions not because they are ethnic by nature but only because they need ethnicity to further nest. For, in the main, in respect to the non-ruling forces, "the Hausa peasant or worker has no interest opposed to that of the Igbo or Yoruba peasant or worker" (Toyo, 1996:11). Consequently, the latter have nothing to gain from ethnic chauvinism but are only being manipulated by the contending ruling elements posing as their ethnic leading lights or spokesmen.

In the same vein, the manipulation of religion to achieve definite political and economic ends has been a very conspicuous feature of the Nigerian political process. The religious manipulation thesis was first popular by Usman (1978), but recent studies have drawn attention to some of its inadequacies. While Kukah(1999:26) underscores the lack of understanding of the "deeply religious nature of the lives of ordinary Nigerians", Egwu (2001:22), maintains that people are susceptible to manipulation because religion "has become an arena of accumulation, and not merely about the control of the theological space, as religious movements support their adherents... to secure employment, organizing marriage and naming ceremonies as well as other material interventions to cushion the effect of the economic crisis"

However, much as the criticisms of the manipulation thesis may hold water, in some respects, there is no denying that in the context of the generation and development of identity consciousness in the nation's body politic, religion has remained a potent force. This could be discerned from all the major controversies and flashpoints associated with religion that the nation has recorded in the course of its political trajectory. These include: the Shariah controversy of the late 70s during the constitutional debates over the introduction of a Sharia court system in the 1979 constitution being formulated; the bitter altercations between Islamic and Christian bodies over the 1986 controversial regularization of Nigeria's observer status of the Organisation of Islamic Countries (IOC) to full membership by the Babangida administration; and the conflicts and violence which attended the introduction of the "political sharia" in some Northern states following the advent of the current civilian democratic dispensation in 1999. All of which would seemed to have only provided opportunities for the political jobbers of both religious divides to manipulate religious forces to attain political relevance.

In this wise, in the murky water of Nigerian politics, the development and congruence of ethnic and religious identities could not but provide a fertile platform for the contending ruling forces to articulate and aggrandize their interest. Only recently, in the wake of the 2019 general elections in which incumbent President Muhammadu Buhari withstood and surmounted an unprecedented conspiracy of elite forces in Nigeria against his candidacy to record a resounding electoral victory over Atiku Abubakar, his main challenger and arrow head of the opposition forces, former President Obasanjo had, in a church function in Delta State, South-South region of the country, renewed the spectre of the so-called 'Fulanisation and Islamisation' agenda of the Buhari Presidency. To be sure, the ethnoreligious and opportunistic antics of Obasanjo not only exposed the displeasure of his political camp with the outcome of the 2019 Presidential election, but also underlies the potency of ethnic and religious manipulation in the contestation for power amongst the various power blocs. In this context, as the locus of power, the state undoubtedly provides further fillip for the process.

\section{The State and Capitalist Development}

The colonial origins of the contemporary Nigerian State have long been established in much the same way that its form and character as well as role in the development of the national political economy have also been articulated (Toyo, 1986; Joseph,1991). It is generally articulated that when the British imperialists created, at the onset of their colonialisation project, "a colonial apparatus of army, police and security" (Kawu, 2006:15), this not only subdued the Nigerian space, but also helped to consolidate the country's incorporation into the global capitalist system. Accordingly, the colonial state simply became the instrument for the exploitation of African resources for the development of metropolitan Europe while paying little or no attention to the development of the colonies.

Even at independence, the domestic ruling forces could only begin a process of 'Nigerianisation' of the colonial state under new conditions of neo-colonialism. As it were, while the personnel that run the post-colonial state had become Nigerians, the philosophical paradigm did not shift and the raison d'etre for the state, viz, the promotion of capitalist development had continued unabated. This stems from their failure to transform the inherited colonial system which ensured the state emerging as "essentially the tool of those in power largely privatized to serve their interest" (Ake, 1995:9).

In the ensuing promotion of capitalist development, the Nigerian state has become an avenue for primitive accumulation of capital. Accordingly, in the contestation for capture, retention and or utilization of state power, the contending social and political forces are, ipso facto, encouraged to develop and employ all means, including identities, at their disposal. For instance, a graphic enunciation of this process has been provided by Joseph (1991) when he analyses and attributes the collapse of Nigeria's second republic to the phenomenon of what he calls "clientalism" and "prebendal politics". This is a form of politics in which the offices of state or positions of control of resources are seen and allocated as "prebends" to "clients" by "patrons" for the selfish aggrandizement of these forces and their community or sectional groups. 
Again, the same process manifest itself even in a situation of falling state responsibility which the country began to experience from the 1980s. This had been the period in which, following the adoption of a structural adjustment programme and the attendant retreat of state from its hitherto central role in development, the state increasingly became unable to meet the basic needs of the Nigerian people. Furthermore, under the same conditions of economic crisis and structural adjustment, and, as the state experiences the resultant crisis of legitimacy and dis-engages from its cardinal responsibility, only constituencies and clients of those who control state power continue to have access to societal resources through patronage. Hence, as pointed out by Jega, $(2000: 27)$

.... under these conditions, groups have tended to rely on identity-based politics to struggle for access to the state and the resources that it controls, or in order to protest exclusion and oppression as well as to demand basic rights and socioeconomic provisioning.

Arising from this process, if in its role as the agent of capitalist development, the Nigerian state has become an avenue for accumulation and development of identities, this also resulted in making the national politics and political struggle for office a 'do or die' affair. Hence because of its high stakes as an avenue for primitive accumulation, the Nigerian political process had, until now, tended to be dominated by the military wing of the ruling forces because of the advantage of their coercive power.

\section{Militarisation of the Political Process}

One of the major political features of post-colonial societies, until very recently, has been the preponderant militarization of their political processes and the attendant perennial political instability. This largely stems from the incessant military incursion into spheres of governance of these countries. This was the lot of Nigeria for a long period after independence when it was unable to ensure that democracy takes firm roots and flourish due to the military's political adventurism.

Apart from the common self-serving arguments of being short 'corrective' and or 'crisis management' regimes to intervene in the political process, or, the 'impending chaos' argument to postpone promised democratisation (Ibrahim, 1995) being advanced by the military political adventurists themselves, the hitherto preponderant militarization of the Nigerian political process has been attributed to the civil-politicians lack of complete faith in, and, their congenital incapacity to consolidate democratic system. In other words, the military, or rather to borrow Awuwo's (1995) phraseology, 'officer-politicians' always capitalized or were motivated by the apparent misgovernance, crass opportunism and venality of the civil politicians to embark and thrive on their adventure in the nation's political process.

Be that as it may, owing to its highly centralised operations and authoritarian predelictions, prolonged military rule in Nigeria had negatively impacted on the county's political trajectory in two major ways. First, the military entrenched the culture of political corruption established by the earlier civilian regimes. This was started during Gowon's regime while Babangida consummated it. As a matter of fact, "under Babangida and Abacha administrations, what used to be known as corruption has become the art of government itself" to the extent that "routine operations of government are being subjected to prebendal rules "(Ibrahim, 1995:6).

However, prebendalism, as noted earlier, cannot but encourage the development of identity consciousness in the country. In fact, by prebendalising the operations of governance in Nigeria, the military eventually encouraged political forces to focus on, and, identify with, or, oppose the identity of state officials at any point in time in the course of the military's political adventurism, and, even beyond.

The second significant impact of prolonged military rule on the nation's body politic was their national destruction of Nigerian federalism, which has been sacrificed, on the altar of their over centralization. Because of their unified command structure, the military are inherently incapable of running a federal state. Consequently, since 1967, beginning with Gowon's creation of twelve states, the military consistently and drastically altered Nigeria's "geo-political realities" from the initial four regions to the now thirty-six states structure. The multiplication of the states has "produced a Jacobean effect that strengthens the centre by eroding the autonomy of the regions", a move that left Nigeria "with a so-called federalism that is for all practical purposes a unitary system with some limited devolution of power to the states"(Ibrahim, 1995:9). With this development, the conditions were not only created for the growth and strengthening of strong dictatorship at the center, but it also accentuated the development of identity consciousness among the Nigerian political forces as they are increasingly compelled to resort to their primordial 'bases' for political survival, relevance and self-actualisation.

\section{June 12 Crisis and the Resurgence of Identity Politics}

Another major factor in the recent increasing secterianisation of politics in Nigeria was the crisis that attended the annulment of the Presidential election of June 12, 1993. The election, which was organized and meant to be the last lap of a long tortuous transition schema of the Babangida regime, was contested for by Bashorun 
M.K.O Abiola of the Social Democratic Party (SDP) and Alhaji Bashir Tofa of the National Republican Convention (N.R.C).

The results of the election pointed to a clear victory by Abiola and also signified a major shift in the locus of power in the country. But after announcing the results from thirteen states and the Federal Capital Territory, the Electoral Commission suspended the exercise on June 16, 1993 purportedly due to an interim injunction issued by an Abuja High Court restraining further announcement of the election results. This was followed one week later, precisely on June 23, 1993 by the annulment of the entire election, suspension of the National Electoral Commission and the abolition of the decree governing the transition programme namely, Decree No. 13 of 1993 (Jibrin, 1997:84).

In subverting its crafted political transition schema and the nation's march to a civil-democratic dispensation, the Babangida regime offered dissimilar and shifting rationalisations for the annulment. The reasons were as implausible as they were self-serving. This is because, from all indications, as I have argued elsewhere (Jibrin,1997), Babangida annulled the election primarily because of the vaulting ambition to perpetuate the stay of his personal oligarchy in office by all means possible. For this reason, the outcome of the election was immaterial and inconsequential to the annulment course in the circumstance.

However, despite the seeming overwhelming national mandate that the outcome of the election would have bestowed on Abiola and the fact that Babangida simply annulled the election for his self-perpetuation scheme in office, the initial denouncement of the annulment by various political forces coupled with subsequent unexampled resistance put up by Abiola and the sundry opposition forces and the attendant hardening of positions by both Babangida and Abacha regimes and their supporters, were later to be given ethnic and religious colourations leading to realignment of forces in the country.

The ethnic-cum-regional colouration of the June 12 crisis would seem to have been engineered by both the government and the opposition forces. On the part of government, witnessed for instance, the Abacha regime's propagandistic articulation of the problematic in publication by the Federal Ministry of Information and Culture (1996:23):

The fact remains that the main problem of June 12, is arguably tribalism. It is the pathetic story of the futile struggle of one group of politician, on ethnic basis, to impose their man on the entire country even when his running mate with whom he shared the mandate, had thrown in the towel. It is also a classic demonstration of the impossibility of attaining tribal hegemony in a general election based on a two-party system in Nigeria, regardless of whatever strategies are employed by those who insist on playing politics, and voting, only on tribal basis.

For their own part, the opposition forces rendered an opportunistic misrepresentation of the candidacy of Abiola prior to, and, after the election, and, subsequent annulment. When Abiola emerged as a presidential candidate of the Social Democratic Party for the June 121993 election, "he was systematically misrepresented and maligned as a stooge and quisling of the military in general and Babangida in particular" (Usman and Abba, 2000:14). However, when he emerged victorious and it became clear that he was unwilling to do anybody's bidding and forfeit his electoral mandate, the same forces turned around to hail his accomplishment as the best thing that ever happened to their ethno-regional bloc, that is, 'the Yoruba race and or Southerners'.

A major consequence of this political development was the resurgence of the seeming hitherto suppressed primordial politicking that is largely hinged on ethno-regional considerations in the country. The renewed ascendency of these tendencies in the nation's political firmament, it should be noted, not only marked the political confrontations of the immediate post-annulment period, and, under the Abacha administration, but it has also continued to shape the character of politics of the current Fourth Republic.

Indeed, in terms of concreate manifestation, the formation and operationalisation of numerous ethnoreligious groupings like the Odua People Congress, Ohanaeze Ndi-Igbo and the Arewa Consultative Forum, in addition to strengthening of existing of ones; and which, together with the agitations for 'power shift' that resulted in the emergence of the Obasanjo Presidency in 1999, are a direct fall out of the June 12 saga.

Besides, the often heated polarization and factionalisation of the political forces over which other geopolitical zone should produce the elected President of the country, which was triggered by President Jonathan Goodluck's succession of late President Yar'adu'a and his subsequent controversial contest and victory in the 2011 general elections, against his party's zoning arrangement, could also be approximated as an indication of how, on the whole, identity politics has been further grounded in Nigeria.

\section{Conclusion}

It is evident that the prevalence of identity politics in Nigeria is much a product and reflection as well, of the country's formation and geo-political configuration as it is of the skewed contemporary political and economic 
trajectory adopted by the self-centered ruling forces. To address the resurgence of identity politics and prevalence, it calls for the consolidation of the prevailing democratic space and deepening of the content of the democratisation project so as to empower good governance and development. This should be accompanied by provision of responsible and accountable leadership at all levels of the society. This is in order to ensure equitable and balanced development of all components of the federation. Above all, the state must be made to rediscover its place as an agent of people-centered development. In other words, a democratized post-colonial state in Nigeria must be at the center of Nigerian renaissance such that instead of seeking political and economic empowerment on ethno-religious and other primordial grounds, all Nigerians will begin to contest and operate on popular-democratic grounds.

\section{References}

Ake, C. 1995, "Socio- Political Approaches and Policies for Sustenable Development in Africa", The Democrat Weekly, September 3: 9.

Albert, O. 1998, "Federalism, Inter- ethnic Conflicts and the Northernisation Policy of the 1950s and 1960s" in Amuwo, K. et al (ed.) Federalism and Political Restructuring in Nigeria. Ibadan: Spectrum Books, 5063.

Alubo, O. 2006, Ethnic Conflicts and Citizenship Crises in the Central Region. Lagos: Eddy Asae Nigeria Press. Amuwo, k. 1995, "Politics in Nigeria since Independence" in Tyoden, S. G. (ed.) Nigeria: Youth Agenda for the 21st Century. Ibadan: Sibon Books, 33- 46.

Egwu, S. G. 1998, "The Question of Identity: Ethnicity, Religion and Nigeria's Political Development", Paper for 'Research Training Workshop and Thesis Support Programme', Centre for Research and Documentation, Kano.

Egwu, S. G. 2001, "Ethnic and Religious Violence in Nigeria", AFRIGOV Working Paper, Jos: St. Stephen Inc. Bookhouse.

Federal Ministry of information and Culture, 1996, June 12 and the Future of Nigerian Democracy. Lagos: Government Printers.

Ibrahim, J. 1995, "Obstacles to Democratisation in Nigeria", Paper for Conference on 'Dilemmas of Democracy in Nigeria', University of Wisconsin- Madison.

Idris, T. 1998, "An Analysis of the Geopolitical Constraints to Economic Development in Nigeria (1960- 1997). Unpublished M. Sc Dissertation.

Jega, A. 2000, "General Introduction. Identity Transformation and the Politics of Identity Under Crisis and Adjustment" in Jega, A. (ed.) Identity Transformation and Identity Politics Under Structural Adjustment in Nigeria. Uppsala: Nordic African Institute, 11-25.

Jega, A. 2000, "The State and Identity Transformation Under Structural Adjustment in Nigeria" in Jega, A., (end.) Identity Transformation and Identity Politics Under Structural Adjustment in Nigeria. Uppsala: Nordic African Institute, 26-44.

Jibrin, I. O. 1997, "June 12 and the Crisis of Democratisation in Nigeria". Unpublished Ph.D Dissertation.

Joseph, R. A. 1991, Democracy and Prebendal Politics in Nigeria: The Rise and Fall of the Second Republic. Ibadan: Spectrum Books.

Kawu, I. M. 2006, "In the Orphanage of neo- liberal Capitalism", Daily Trust, September 21:48.

Kukah, M. H. 1993, Religion, Politics and Power in Northern Nigeria. Ibadan: Spectrum Books.

Kukah, M. H. 1999, Democracy and Civil Society in Nigeria. Ibadan: Spectrum Books.

Kuna, M. J. 2001, "Contested Boundaries, Shifting Solidarities: Democracy and the Politics of Identity in Nigeria', Paper for 'Annual Research Training Workshop', Centre for Research and Documentation, Kano.

Kuna, M. J. 2003, "Coloniality and the Geography of Conflicts in Northern Nigeria", Paper for Conference on "Transformation of Northern Nigeria", Arewa House, Kaduna.

Nnoli, O. 1978, Ethnic Politics in Nigeria. Enugu: Fourth Dimension Publishers.

Salamone, F. 1992, "Nigeria, A Nation of 'Ringers' ", Geneve- Afrique No. 1,57-75.

Suberu, R. T. 1996, Ethnic Minority Conflicts and Governance in Nigeria. Ibadan: Spectrum Books.

Toyo, E. 1986, "A Theory of the National Question and Ethnicity in Nigeria", Paper for Seminar on 'The National Question in Nigeria: Its Historical Origins and Contemporary Dimensions', Abuja.

Tyoden, S. G. 1996, " The Minorities Factor in Nigerian Federalism" in Elaigwu, J. I. and Akindele, R. A. (ed.) Foundations of Nigerian Federalism 1960- 1995. Jos: Institute of Governance and Social Research, 246265.

Usman, Y. B. and Abba, A., 2000, "The Misrepresentation of Nigeria", CEDDERT Occasional Publication 12000, Kaduna: Vanguard Printers and Publishers.

Usman, Y. B. 1987, The Manipulation of Religion in Nigeria. Kaduna: Vanguard Publishers. 